\section{Enquadramento jornalístico do impeachment de Dilma Rousseff em revistas brasileiras sob uma perspectiva de gênero}

\author{
Marcos Paulo da Silva \\ Raquel de Souza Jeronymo
}

\section{Resumo:}

O estudo constitui uma análise de enquadramento jornalístico da cobertura realizada pelas revistas semanais brasileiras Veja e IstoÉ durante o processo de impeachment da ex-presidenta Dilma Rousseff, concluído em agosto de 2016, adotando-se uma perspectiva de gênero. Utiliza-se uma abordagem metodológica multimodal, agregando às funções clássicas de enquadramento o estudo das fontes, dos canais de informação e das estratégias retóricas aplicados nas abordagens jornalísticas. Infere-se, a partir da análise, que o enquadramento jornalístico do processo de impeachment construído pelas revistas cumpre um papel político desestabilizador no jogo de poder e sofre influências do universo sexista que historicamente caracteriza a política deliberativa no país.

Palavras-chave: Enquadramento jornalístico. Dilma Rousseff. Impeachment.

Journalistic framing of Dilma Rousseff's impeachment in brazilian magazines from a gender perspective

\begin{abstract}
:
This study constitutes a journalistic framing analysis of the Brazilian weekly magazines Veja and IstoÉ coverage of the impeachment process of former president Dilma Rousseff, which was concluded in August 2016, from a gender perspective. A multimodal analysis is used as a methodological approach, adding some elements to the classic functions of framing, such as the study of sources, information channels, and rhetorical strategies related to journalism. It is possible to infer that the journalistic framing of the impeachment process by the two Brazilian magazines plays a destabilizing political role in the power game, and that it suffers influences from the sexist universe that historically characterizes the deliberative politics in the country.
\end{abstract}

Keywords: Journalistic framing. Dilma Rousseff. Impeachment.
Recebido em: 11.04.21

Aprovado em: 24.08.21

Marcos Paulo da Silva

Professor Associado da Universidade Federal de Mato Grosso do Sul. Doutor em Comunicação Social pela Universidade Metodista de São Paulo (UMESP).

E-mail:marcos.paulo@ ufms.br

\section{Raquel de Souza} Jeronymo

Mestre pelo Programa de Pós-Graduação em Comunicação da Universidade Federal de Mato Grosso do Sul (UFMS).

E-mail: raquels.jeronymo@gmail.com 


\section{Gênero, política e mídia}

T

mbricado no contexto de tensionamentos entre a política representativa e as questões de gênero, o presente estudo propõe o desenvolvimento de uma análise multimodal de enquadramento jornalístico da cobertura realizada por duas das maiores revistas semanais brasileiras - Veja e IstoÉ - sobre o processo de impeachment de Dilma Rousseff (PT) durante seu segundo mandato (2014-2016). Após um ano marcado por grande instabilidade política e econômica no Brasil, permeado por denúncias de corrupção e investigações de grande repercussão midiática, como a CPI da Petrobras e a Operação Lava Jato, protestos de manifestantes contrários e favoráveis à presidenta, dentre outros ocorridos, Dilma foi acusada, no final de 2015, de ter cometido crime de responsabilidade fiscal, quando foi autorizada pela Câmara dos Deputados a abertura do processo de impeachment.

O tratamento jornalístico dado ao tema desvela a estreita relação no Brasil entre a representação política e a representação midiática a partir de questões de gênero (MATOS, 2015; MIGUEL, BIROLI, 2009; SARMENTO, 2013). Num vértice histórico, a filósofa francesa Simone de Beauvoir é uma das pioneiras na discussão sobre as distinções sociais entre homens e mulheres e, ainda que não utilize o conceito "gênero", apresenta um princípio que fundamentaria futuramente a distinção entre sexo e gênero, pois, por mais que defenda a importância dos dados biológicos, "sendo o corpo o instrumento de nosso domínio do mundo", afirma que os mesmos não bastam para definir uma hierarquia dos sexos (BEAUVOIR, 1970, p. 52).

A socióloga brasileira Moema Viezzer (1989) é outra pensadora que desenvolve pensamento que vai de acordo ao entendimento de Beauvoir. No livro " $O$ Problema Não Está na Mulher", Viezzer (1989) traça a distinção entre sexo - enquanto característica fisiológica - e gênero, que tem um sentido mais amplo, cultural e sociológico. Assim, "enquanto o sexo de cada um é um dado fisiológico, a conduta sexual pode ser, no entanto, psicológica e socialmente diferente", pois embora os dois termos "se encontrem vinculados entre si de maneira inseparável na mentalidade geral, não existe uma dependência rígida e irrestrita entre ambas as dimensões" (VIEZZER, 1989, p. 107-108). O vocábulo gênero, portanto, seria empregado para marcar as diferenças psicológicas e culturais que determinam os papéis na sociedade, e estaria inserido historicamente dentro do plano das relações sociais, que, como conceitua a socióloga, "são relações mútuas que se estabelecem entre os seres humanos para a produção e a reprodução das condições materiais de existência" (VIEZZER, 1989, p. 108).

A subordinação é o conceito geral da dominação masculina em qualquer classe considerada, tanto entre os trabalhadores quanto em meio aos burgueses da classe dominante, e se manifesta através da exploração, da desigualdade, da repressão, do machismo, da discriminação, dentre outras formas (VIEZZER, 1989). Segundo a autora: "A emergência do conceito de relações sociais de gênero se elaborou como parte da busca de uma teoria feminista que contemplasse, de maneira globalizante, todas as questões relacionadas com a subordinação da mulher ao homem", e ao longo dos anos se tornou "um dos principais instrumentos de análise das condições em que vivem as mulheres em relação aos homens em qualquer tipo de sociedade (VIEZZER, 1989, p. 111)

Portanto, essa situação de subordinação da mulher ao homem nos mais diferentes tipos de sociedade, especialmente por meio da divisão sexual do trabalho, ainda que apresentada como "natural", "sempre respondeu a interesses econômicos e políticos institucionalizados e transmitidos de geração a geração" (VIEZZER, 1989, p. 115). Nesse contexto, "se as relações entre homens e mulheres são relações sociais, históricas, então elas não são imutáveis e fixas", mas assumem 
formas diferentes em cada período histórico de uma determinada formação socioeconômica e devem ser analisadas levando esses fatores em consideração e não isoladamente, pois "não constituem o único princípio disciplinador das sociedades em geral" (VIEZZER, 1989, p. 115-116).

A pesquisadora brasileira Marlise Miriam de Matos assinala a presença da hierarquização de gênero na política dentro do "conjunto de entradas institucionais, de ações práticas no mundo e de significações simbólicas" que a teoria feminista denomina como patriarcado (MATOS, 2015, p. 25). Segundo a autora "a normatividade patriarcal se organizou a partir de um enraizamento que há muito transbordou a ordem social (...) e está transversalizada no sistema econômico e cultural, indo também para a ordem política" (MATOS, 2015, p. 25). Essa normatividade opera na divisão sexual do trabalho, inclusive na política, colocando as mulheres em posição desvantajosa. Para Matos (2015, p. 28), o patriarcado se apresenta, por exemplo, no acúmulo de funções das mulheres, que não só trabalham mas cuidam, muitas vezes sozinhas, dos afazeres domésticos, das crianças e da família, o que "torna a jornada da participação e do ativismo político das mulheres de um custo altíssimo para elas", e está também na continuada deslegitimação "da atuação pública e política da mulher, no enviesado e estereotipado (quando não estigmatizado e deteriorado) julgamento moral negativo o qual as candidaturas (e a efetiva eleição) de mulheres têm que superar e ultrapassar".

Desse modo, para a autora, o patriarcado atua garantindo o padrão dos privilégios políticos masculinos "no âmago da democracia representativa brasileira e mundial, na constituição mesma das regras de nosso sistema político-eleitoral" (MATOS, 2015, p. 28), sendo o gênero não apenas um marcador de diferenças, "mas princípio básico de hierarquização e dominação que assinala injustamente espaços e distribui recursos de poder desequilibradamente e de forma antidemocrática entre homens e mulheres" (MATOS, 2015, p. 25). Explicita a autora:

Aqui nos parece inegável que a variável "gênero" é profundamente, densamente, originariamente "política" porque é patriarcal e é igualmente "explicativa" para o fenômeno persistente da subrepresentação (ou da exclusão feminina). O patriarcado institucionalizado no Estado compreende e explica tal fenômeno, localizando a dimensão hierárquica do poder político masculino, assimétrico e vantajoso exclusivamente para os homens, no coração mesmo da nossa representação política (MATOS, 2015, p. 26).

$\mathrm{Na}$ outra ponta do processo de representação, a mídia é entendida por Luis Felipe Miguel e Flávia Biroli (2008, p. 25) como uma esfera que "difunde visões da realidade social que tendem a confirmar e naturalizar as visões já incorporadas pelos agentes (homens e mulheres) com relação às hierarquias de gênero". Nesse contexto, considera-se neste estudo o pressuposto de que não seria suficiente desenvolver uma análise da cobertura midiática dada à ex-presidenta Dilma Rousseff - e mais especificamente ao processo que resultou na sua deposição - que não levasse em consideração a dominação histórica sofrida pelas mulheres e a luta travada por elas por uma igualdade de tratamento e de direitos, em especial no terreno da representatividade política. Miguel e Biroli (2009, p. 56) fundamentam suas reflexões na confluência entre as concepções de gênero, política e mídia. Os autores buscam observar "os mecanismos que, em cada uma dessas esferas, e de modo complementar, funcionam de modo a restringir não só a presença de mulheres no campo político como também as formas que tal presença assume".

Miguel e Birolli (2009, p. 72) sublinham que "a sub-representação no noticiário jornalístico é mais acentuada do que no campo político”, ou seja, há ainda menos deputadas e senadoras nas pautas jornalísticas do que na Câmara e no Senado, e essa configuração das relações entre os gêneros é apresentada como "natural", o que acaba por reforçar ainda mais a exclusão feminina na política. Além disso, “o âmbito considerado 'próprio' para a política feminina [...] é também aquele que 
menos impulsiona as carreiras políticas e que possui menor visibilidade na cobertura jornalística da política" (MIGUEL; BIROLI, 2008, p. 24).

$\mathrm{O}$ ingresso feminino na política mostra-se cheio de obstáculos peculiares que ultrapassam o próprio campo, pois seu comprometimento com a gestão do espaço doméstico e com o cuidado com a família, heranças de uma sociedade patriarcal onde estereótipos de gênero ainda estão fortemente presentes, "dificulta que assumam carreiras profissionais que, como a política, exigem flexibilidade de horários, uma disponibilidade quase inesgotável de tempo e ausências frequentes" (MIGUEL; BIROLI, 2008, p. 38). Para os autores, "qualidades que tendem a ser associadas à fala feminina, como a emotividade, desvalorizam o discurso no interior do campo político", assim como "a abertura aos argumentos dos outros, que também faz parte do treinamento social das mulheres, tende a ser interpretada como sinal de deferência (isto é, de subalternidade) ou de hesitação", e até mesmo "o tom de voz mais agudo é recebido com menos respeito pela audiência" (MIGUEL; BIROLI, 2008, p. 26).

Quando não apresentam algumas dessas características tidas como "femininas", caso de Dilma Rousseff, apresentada na mídia muitas vezes como "fria" e "durona", ainda assim as mulheres têm suas qualidades questionadas. Trata-se do fenômeno denominado double-bind, "um impasse psicológico criado quando demandas contraditórias são feitas de um indivíduo, de modo que não importa qual diretiva seja seguida, a resposta será interpretada como incorreta" (CATALYST, 2007, p. 1, tradução nossa). Rayza Sarmento (2013, p. 14) explica que enquanto em alguns países como a Alemanha a feminilidade e a boa atuação política são tidas como incompatíveis, situação que forçou lideranças como a chanceler Angela Merkel a não expor determinadas características vistas como femininas, no Brasil isso se deu de forma oposta, com a necessidade de reafirmação de certa feminilidade por parte de Dilma. “Um jeito mais assertivo, e 'durão', comumente não associado às mulheres, sempre foi a marca da presidenta, que, por vezes, precisou apaziguá-lo para tornar-se mais feminina aos olhos públicos" (SARMENTO, 2013, p. 14).

A pesquisadora estadunidense Kathleen Jamieson já havia explicitado o fenômeno do double-bind em uma publicação de 1995. Para a autora, quando as mulheres se conformam com estereótipos femininos como serem "brandas" ou "fracas" são julgadas incompetentes, mas quando são "duras" ou "fortes" são julgadas como se estivessem agindo inadequadamente para uma mulher (JAMIE-

${ }^{1} \mathrm{O}$ enquadramento, para Erving Goffman, possibilita análises sobre como cada sujeito se envolve em uma dada situação social e como utiliza os quadros sociais como estruturas cognitivas fundamentais. Cada quadro ou esquema primário "permite a seu usuário localizar, perceber, identificar e etiquetar um número aparentemente infinito de ocorrências concretas, definidas em seus termos", mesmo que de maneira inconsciente (GOFFMAN, 2012, p.45). Pelas limitações intrínsecas deste artigo, não se pretende ampliar a discussão sobre o conceito trabalhado pelo pensador estadunidense.
SON, 1995). Pesquisa realizada pela Organização Não-Governamental Catalyst respalda essas afirmações. Segundo a organização, as mulheres ainda são vistas como "líderes atípicas", por isso "presas entre escolhas impossíveis, aquelas que tentam se adaptar aos comportamentos de liderança tradicionais - isto é, masculinas - são condenadas tanto se o fizerem como se não o fizerem" (CATALYST, 2007, p. 1, tradução nossa).

Nesse cenário, as associações entre gênero, política e mídia sedimentam o caminho a ser percorrido para analisar o enquadramento jornalístico do impeachment de Dilma Rousseff sob a hipótese de que os estereótipos de gênero estabelecem muitas vezes os "quadros primários" (GOFFMAN, 2012) ${ }^{1}$ - para além dos enquadramentos técnicos - acionados tanto pelos jornalistas na elaboração da cobertura política quanto pelo público, pelos políticos homens e até mesmo pelas próprias mulheres no horizonte em questão.

\section{Opções metodológicas}

Para o desenvolvimento da análise de enquadramento, o recorte empírico escolhido baseia-se em duas das revistas semanais de maior circulação no Brasil: Veja, do Grupo Abril, e IstoÉ, da Editora Três, que juntas possuíam tiragem média de mais de 1 milhão de exemplares no período analisado, segundo Associação 
Nacional de Editores de Revistas (ANER). Por opção metodológica, foram selecionados os exemplares referentes a momentos considerados como pontos de inflexão do impeachment (ver figura 1), selecionando-se as edições referentes a esses recortes, a saber: edições 2401 (9 de dezembro de 2015), 2419 (20 de abril de 2016), 2423 (13 de maio de 2016), 2436 (12 de agosto de 2016) e 2439 (01 de setembro de 2016) de IstoÉ; e 2455 (9 de dezembro de 2015), 2474 (20 de abril de 2016), 2478 (18 de maio de 2016), 2491 (17 de agosto de 2016) e 2494 (07 de setembro de 2016) de Veja, totalizando 10 edições.

\section{Figura 1 - Momentos-chave do processo de impeachment de Dilma Rousseff}

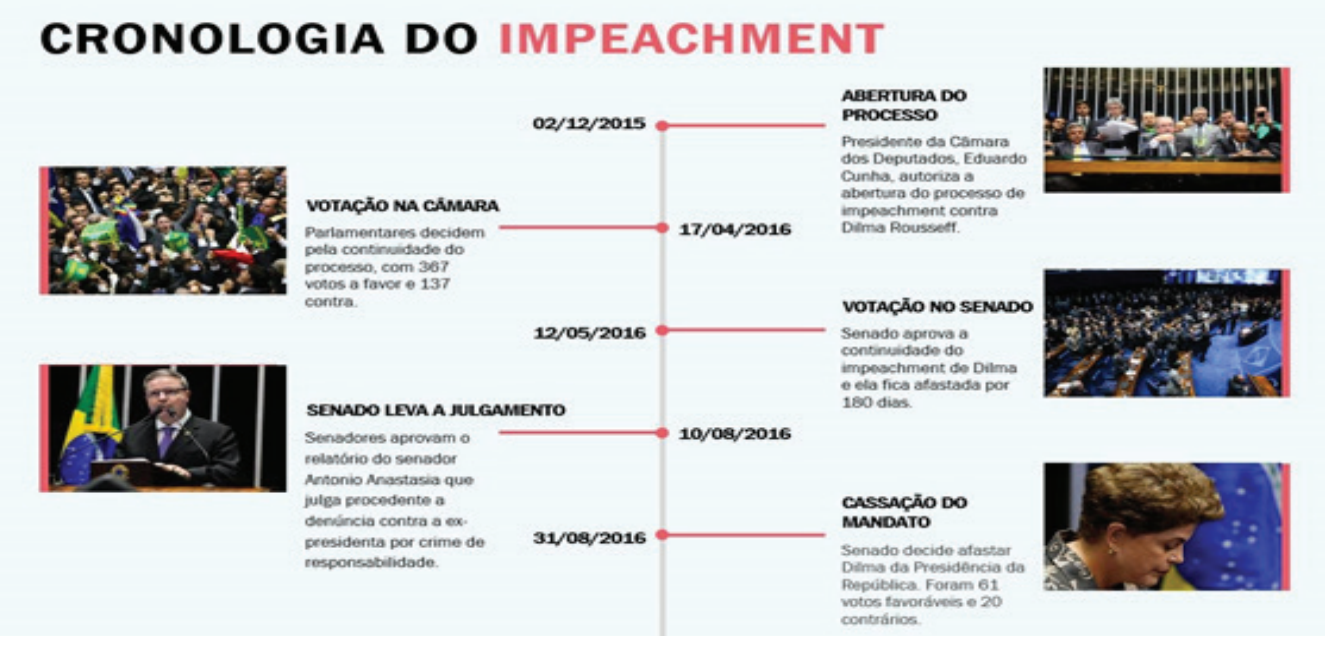

Fonte: Diagrama desenvolvido para as finalidades deste estudo.

A escolha dos elementos de cada item jornalístico analisado ancora-se na visão multiparadigmática proposta por D’Angelo (2002) e em uma adaptação do conceito de enquadramento multimodal elaborado por Wosniak, Lück e Wessler (2014) com aplicação já realizada ao processo de impeachment - mas com um corpus distinto, referente a jornais impressos diários - pelos pesquisadores brasileiros Rizzotto, Prudencio e Sampaio (2017). A proposta desta última abordagem foi analisar os produtos jornalísticos em três níveis: visual, narrativo e de enquadramento. Os autores aliam-se, nesse sentido, à análise proposta por Entman (1993) a partir das quatro funções do enquadramento - definição do problema, interpretação causal, avaliação moral e recomendação de tratamento - a outras configurações da informação jornalística. No caso do presente estudo, todavia, para além das funções clássicas de enquadramento, são analisadas as fontes e os canais de informação, bem como as estratégias retóricas identificadas no conteúdo jornalístico ${ }^{2}$. Entende-se que tal protocolo de análise mostra-se plausível para a identificação - no interior da cobertura jornalística do impeachment - dos quadros de referência primários (GOFFMAN, 2012) para uma análise necessária sob uma perspectiva de gênero.
${ }^{2} \mathrm{Na}$ pesquisa mais ampla que serve de base para o trabalho foram analisados também os enquadramentos visuais a partir das imagens apresentadas na cobertura jornalística. Todavia, em razão das limitações de espaço intrínsecas do artigo, optou-se por considerar aqui os elementos mencionados. 
Figura 2 - Diagrama que ilustra o modelo de análise proposto no presente estudo.

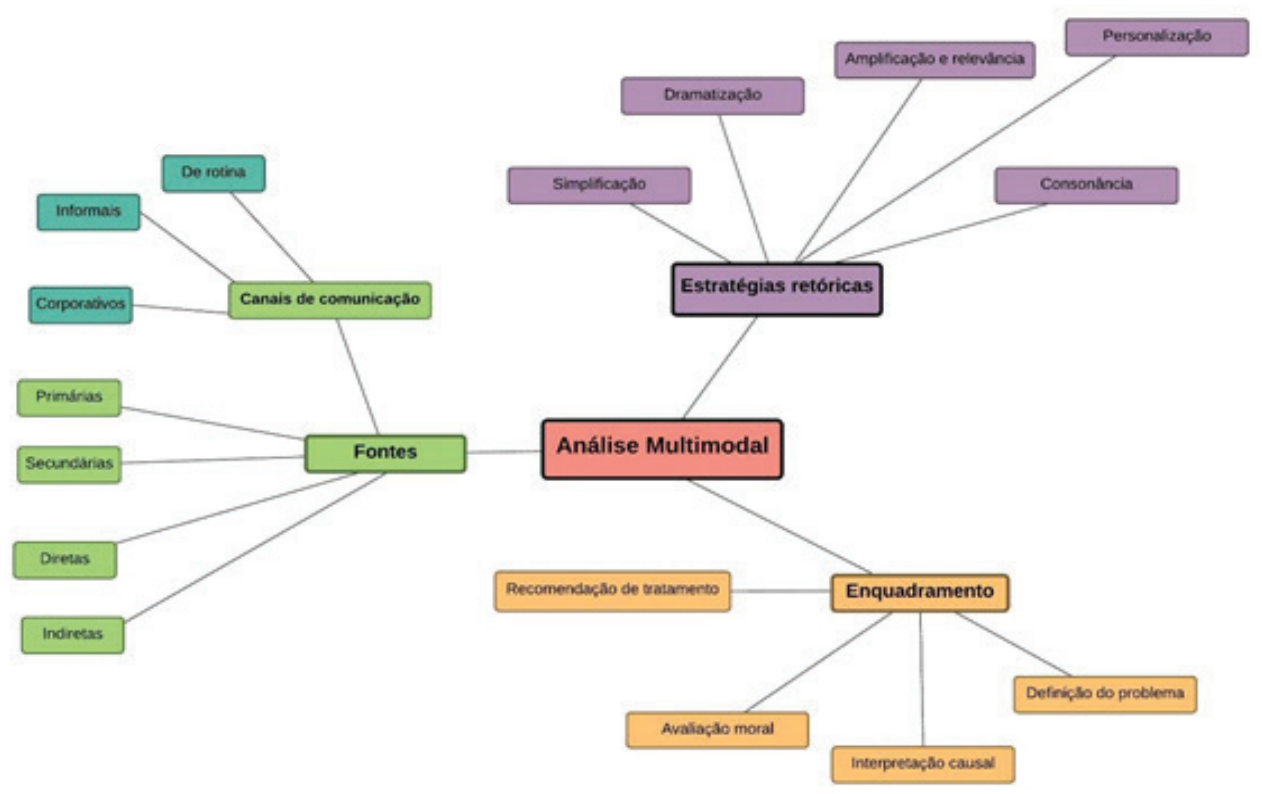

Fonte: Elaboração própria baseada no modelo de Rizzotto, Prudencio e Sampaio (2017).

\section{Análise das fontes e dos canais de informação}

A análise das fontes mencionadas nas matérias examinadas baseia-se na pesquisa de Leon Sigal (1974) e no conceito de canais de informação - "caminhos pelos quais as informações atingem os repórteres" (Sigal, 1974, p. 120, tradução nossa) - elaborado pelo autor, que classifica tais canais em três categorias: de rotina, informais e corporativos. Na primeira categoria estão inclusos procedimentos oficiais, comunicados e coletivas de imprensa, palestras, cerimônias e outros tipos de eventos não-espontâneos. Os "canais informais" incluem vazamentos, processos não-governamentais, reuniões de associações ou convenções sindicais e também matérias publicadas em outros veículos de imprensa. Por fim, os "canais corporativos" constituem as entrevistas e apurações realizadas por iniciativa dos próprios repórteres, eventos nos quais os jornalistas testemunham em primeira mão e as conclusões ou análises tomadas nesse processo (SIGAL, 1974).

Para categorizar os canais de informação utilizados por Veja e IstoÉ na construção das matérias sobre o impeachment, são utilizadas as mesmas classificações do autor norte-americano. Por opção metodológica, embora não constem na formulação original de Sigal (1974), as declarações obtidas pelas revistas via redes sociais na internet foram classificadas como pertencentes ao "canal informal". A última categoria, denominada "canal não identificado", refere-se a situações em que não é possível determinar qual foi o canal utilizado para a obtenção da informação analisada. Outra categoria de análise das fontes noticiosas utilizadas baseia-se nos conceitos traçados pelo autor Lawrence Soley (1992), que divide as fontes jornalísticas em duas classificações: os news makers, que participam ativamente dos eventos noticiosos; e os news shapers, que são procurados pela mídia na busca por "informações privilegiadas, panos de fundo ou previsões sobre o resultado das narrativas que ainda estão em desdobramento" (SOLEY, 1992, p. 2, tradução nossa). Serão classificadas como news makers as chamadas "fontes primárias" e como news shapers as "fontes secundarias".

Nas duas revistas, o canal de rotina mostra-se substancialmente o mais utilizado, conotando o oficialismo das coberturas e, por conseguinte, no seio do 
sistema representativo brasileiro (conforme debatido acima), o reforço de estereótipos de gênero. No caso de IstoÉ, o canal de rotina constitui cerca de $59 \%$ do total de 109 ocorrências; em Veja, são 66\% das 62 ocorrências. O canal corporativo e os casos nos quais não é possível identificar o canal empregado estão praticamente empatados na análise de IstoÉ, ambos com aproximadamente $15 \%$, seguidos pelo canal informal, com 11\%. Em Veja, as ocorrências nas quais o canal de informação não pôde ser identificado somam $16 \%$, seguidas pelos canais informal $(9,7 \%)$ e corporativo (8,1\%). Em ambas as revistas, o canal de rotina é majoritariamente utilizado para fontes oficiais, a exemplo de políticos, empresários, autoridades e instituições de pesquisa, levando-se em consideração que as declarações utilizadas nas matérias são retiradas de coletivas de imprensa, eventos oficiais, notas e relatórios elaborados para os veículos jornalísticos e delações premiadas divulgadas pela Justiça, o que denota um caráter oficialesco na cobertura e explicita a desigualdade de vozes também em uma perspectiva de gênero (MIGUEL; BIROLI, 2009; SARMENTO, 2013). A distribuição entre fontes primárias e secundárias mostra-se muito equilibrada nas duas análises, com aproximadamente $51 \%$ de fontes secundárias e $49 \%$ de fontes primárias em IstoÉ e $52 \%$ de fontes primárias e $48 \%$ secundárias em Veja.

Tabela 1 - Canais de informação das matérias analisadas em IstoÉ

\begin{tabular}{ccc}
\hline Rotina & 64 & $58,7 \%$ \\
Corporativo & 17 & $15,6 \%$ \\
Informal & 12 & $11,0 \%$ \\
Não identificado & 16 & $14,7 \%$ \\
Total & 109 & $100 \%$ \\
\hline
\end{tabular}

\section{Canais de informação das matérias analisadas em Veja}

\begin{tabular}{ccc}
\hline Rotina & 41 & $66,1 \%$ \\
Corporativo & 5 & $8,1 \%$ \\
Informal & 6 & $9,7 \%$ \\
Não identificado & 10 & $16,1 \%$ \\
Total & 62 & $100 \%$ \\
\hline
\end{tabular}

Fonte: Tabela desenvolvida pelos autores para os fins deste estudo, a partir da análise das matérias selecionadas de Veja e IstoÉ, baseada no modelo de Sigal (1974).

O canal corporativo é utilizado em $92 \%$ das ocasiões (12 de 13 fontes) no caso de IstoÉ para apresentar fontes primárias, sendo $36 \%$ destas ocorrências advindas de livros, músicas e outras plataformas consultadas. Os outros 67\% representam os chamados news shapers, "especialistas" consultados para analisar, embasar e comentar informações da matéria. Quanto às 14 fontes acessadas por meio do canal de rotina em Veja, dez possuem algum envolvimento atual ou prévio com a política, $71 \%$ do número total. A revista recorre ao canal corporativo para acessar apenas três fontes em todas as matérias; duas delas se enquadram na categoria dos news shapers discutida por Soley (1992), ambas citadas na matéria "Visão da História" (edição no 2494). O canal informal é utili- 
zado por ambos os veículos para apresentar citações diretas e indiretas extraídas de vazamentos de informações, processos não-governamentais, dados oriundos de outros veículos midiáticos e postagens em redes sociais. Em 16 ocorrências de IstoÉ não é possível identificar qual o canal utilizado pelos jornalistas para obtenção das declarações. Quatro delas referem-se ao ex-presidente Luiz Inácio Lula da Silva, número total de vezes em que ele aparece como fonte nas matérias analisadas. Três ocorrências concernem à própria Dilma, o que denota - em um vértice de análise sob a perspectiva de gênero - que a presidenta, embora foco da publicação, não é ouvida diretamente pela revista, e duas ao ministro-chefe da Casa Civil durante seu segundo mandato, Jaques Wagner. Já em Veja as situações onde não se mostra possível identificar o canal utilizado representam dez ao todo, em $60 \%$ dos casos envolvendo políticos e em $40 \%$ dos casos onde, além do canal, as fontes também não são identificadas, a exemplo de formulações genéricas como "antigo auxiliar de Dilma" (edição no 2455), "um senador" (edição $n^{\circ}$ 2474) e "um de seus ex-ministros" (edição no 2478).

Das fontes secundárias utilizadas, excluindo-se as que não são identificadas, bem como as de natureza documental, fruto do aprofundamento da pesquisa jornalística, faz-se pertinente uma análise do perfil dos agentes ouvidos pelas revistas. Em seu estudo sobre os news shapers no contexto estadunidense no final dos anos 1970, Soley (1992) já concluíra que o grupo de especialistas consultados pelos jornalistas mostrava-se muito restrito, sendo constituído por poucos indivíduos em todo o território do país em termos étnicos, de afiliação institucional e - com relação especial à abordagem deste estudo - de gênero, conotando um vínculo com as matrizes históricas da dominação masculina. Esse pressuposto respalda em certa medida os resultados obtidos pela presente análise. Por intermédio de buscas em mecanismos de pesquisa nos meios de comunicação brasileiros considerados de referência (ZAMIN, 2014), identifica-se que dos oito "especialistas" consultados nas edições escolhidas de Veja, cinco são encontrados com facilidade no mesmo período como fontes de pelo menos cinco outros veículos. Das 18 fontes restantes de IstoÉ, oito exerciam algum tipo de cargo político, como deputados ou senadores, quando mencionadas. Dessas, cinco pertenciam ao PT ou a partidos aliados de Dilma e três à oposição. Apesar de a divisão quantitativa denotar uma tendência favorável ao governo petista, os políticos governistas foram mencionados todas as vezes por declarações e entrevistas concedidas em plenário ou via notas oficiais, enquanto o até então senador e presidente do PSDB, Aécio Neves, candidato nas eleições presidenciais de 2014 em disputa com Dilma no segundo turno, foi entrevistado pela revista em duas ocasiões, nos textos "A pior travessia" (edição no 2401) e "O acordão para salvar Dilma” (edição n 2439).

Quanto ao recorte específico de gênero, além da própria Dilma Rousseff, das 43 fontes consultadas pela IstoÉ, número que leva em consideração somente fontes identificadas e pessoas físicas, apenas seis são mulheres. Desse número, três são fontes primárias e três secundárias, e das fontes secundárias apenas uma pode ser enquadrada na condição de "especialista", consultada para fornecer pano de fundo para a matéria. Dos dez "especialistas" consultados pela revista, portanto, nove são homens. Das 18 fontes ouvidas por Veja, apenas três são mulheres. Desse número, uma caracteriza-se como fonte primária e duas como secundárias.

Nesse ínterim, a análise das fontes e dos canais de informação desvela como a mídia pode atuar, ainda que implicitamente, no reforço do desequilíbrio de gênero nas instâncias representativas. Do ponto de vista da produção de sentidos, mesmo que Dilma Rousseff constituísse na maior parte das vezes o tema central das matérias, os veículos não realizaram entrevistas diretas com ela, sendo suas falas resumidas a procedimentos do canal de rotina - discursos 
oficiais, comunicados, dentre outros. Desse modo, não obstante a ex-presidenta seja apresentada como fonte primária em diversas ocorrências, essa alocação simbólica promovida pela instância midiática - ainda que decorrente de opções editoriais legitimadas no interior do jogo de forças em questão ${ }^{3}$ - conota um distanciamento dos enunciatários e produz efeito de descrédito a suas declarações. Ademais, das fontes consultadas por IstoÉ, apenas $14 \%$ são mulheres. De todos os "especialistas" mobilizados pela revista, 90\% são homens. Quanto à Veja, da totalidade de fontes consultadas, excluindo as menções à própria Dilma Rousseff, apenas $17 \%$ são mulheres. Tratam-se de dados importantes que explicitam a disparidade de gênero no espaço de enunciação de duas das maiores revistas semanais brasileiras em sintonia com as reflexões de Matos (2015), Miguel e Biroli (2009) e Sarmento (2013).

\section{Análise das funções de enquadramento}

Esta etapa da análise volta-se ao estudo das funções de enquadramento com base na proposição original de Robert Entman (1993). O autor apresenta uma definição para o conceito que envolve ações de seleção e saliência. Enquadrar, para Entman (1993, p. 52, tradução nossa), é "selecionar alguns aspectos de uma realidade percebida e torná-los mais salientes em um texto comunicacional" de modo a oferecer quatro funções: "promover uma definição de problema particular, uma interpretação causal, uma avaliação moral e/ou uma recomendação de tratamento para o item descrito". Entman (1993) afirma também que os quadros têm pelo menos quatro posições no processo comunicativo: o comunicador, o texto, o receptor e a cultura. Nesta etapa da análise, o foco recai sobre a cultura (uma vez que se adota a hipótese de que o jogo de forças relacionado à representação midiática do tema manifesta-se sob uma problemática de gênero) e sobre o texto, que contém quadros técnicos que são manifestados pela presença ou pela ausência de palavras-chave, imagens estereotipadas, fontes de informação e frases que fornecem o reforço de grupos de fatos ou decisões (ENTMAN, 1993, p. 52).

Os periódicos Veja e IstoÉ apresentam resultados semelhantes na análise das funções de enquadramento, por isso opta-se por abordá-los conjuntamente, mas enfatizando suas particularidades. Nas 20 matérias analisadas, totalizando dez de cada revista, IstoÉ apresenta definição de problemas em $40 \%$ e Veja em $60 \%$. Veja faz o diagnóstico de causas em $40 \%$ das matérias, enquanto em IstoÉ essa função de enquadramento não é utilizada. Ambas sugerem soluções em apenas $20 \%$ do total de reportagens, mas promovem julgamentos morais na totalidade delas - 0 que merece ser ressaltado do ponto de vista analítico.

Com relação às definições de problema, as mais recorrentes estão relacionadas ao cenário econômico do país ou a casos de corrupção. Na matéria "Impeachment não é guerra" (edição no 2455), de Veja, é apresentado um "ambiente de depressão econômica e corrupção generalizada", onde "a inflação e o desemprego sobem rapidamente", "as indústrias se recolhem ao mínimo de atividade produtiva" e "o comércio prevê o pior Natal em décadas". Todavia, na matéria "Dilma cai no limbo", a ex-presidenta é responsabilizada diretamente e unilateralmente pelos problemas apresentados. A matéria "A pior travessia" (edição no 2401), de IstoÉ, define o cenário econômico como a "maior crise da história recente", e a reportagem "A história se repete, 23 anos depois", da mesma edição, menciona, além da "crise econômica brutal", uma "base política em frangalhos" e baixos índices de popularidade atribuídos a Dilma.

Enquanto IstoÉ se isenta de fazer um diagnóstico de causas para tentar identificar as forças que criam os problemas, Veja o faz de forma superficial. Na edição $n^{\circ} 2455$ de Veja, os motivos apontados para a extensa lista de problemas
${ }^{3}$ Cabe ressaltar que, por sua natureza calcada na produção de sentidos, a análise não permite verificar se Dilma Rousseff não foi devidamente procurada pelas revistas Veja e IstoÉ ou se optou por não se manifestar, delegando funções a assessores(as), advogados e outros(as) agentes do espectro político. 
apresentados na matéria "Impeachment não é guerra" são lideranças políticas corruptas, que estão "ocupadas demais tentando salvar a si mesmas das investigações" e os níveis recordes de reprovação popular do governo Dilma. Na reportagem "O Último Capítulo" (edição no 2474), a ex-presidenta é apontada como "incapaz de restabelecer o diálogo com os setores produtivos e o Congresso", bem como na matéria "Visão da História" (edição no 2494) a culpada é a "polarização". Quanto às soluções sugeridas, em três das quatro matérias onde esse recurso é identificado, o impeachment é apresentado como alternativa inescapável - ou mesmo como uma "luz a se insinuar no fim do túnel em meio ao breu" (IstoÉ, edição no 2401). Na edição no 2436 de IstoÉ, em "A era Dilma se aproxima do fim", a saída definitiva da presidenta supostamente "fará com que o presidente em exercício Michel Temer atue com mais desprendimento para colocar em marcha as reformas necessárias ao País". Nas demais matérias, a falta de outras soluções deixa implícita a mesma conclusão.

Os julgamentos morais, presentes em todas as matérias do recorte, em ambas as revistas, reforçam a tese - e destacam a problemática das desigualdades de gênero. Para a Veja, "na prática, o impeachment é um processo essencialmente político" (edição no 2455). A publicação admite que apesar de formalmente Dilma ser "acusada de recorrer a bancos públicos para despesas de responsabilidade do Tesouro Nacional", "na prática, está sendo julgada pelo conjunto da obra, da recessão econômica aos casos de corrupção" (edição no 2478). A matéria "A pior travessia" (edição no 2401), de IstoÉ, menciona que "a oposição aposta que a popularidade de Dilma tende a se deteriorar até lá, com o aprofundamento da crise, o que pavimentará o caminho para apeá-la do poder", e completa: "Michel Temer, cujo discurso oportunamente entoado no final a última semana soa como música aos ouvidos de todos os atores políticos interessados numa inflexão".

Infere-se que o fato de o próprio Michel Temer não ter sido acusado pelas publicações de ter cometido atos criminosos, embora o processo eleitoral dissesse respeito à chapa que ambos integravam, se relaciona implicitamente ao desequilíbrio no tratamento das questões de gênero. Há ainda outros julgamentos morais apontados especificamente por Veja que se associam à temática de gênero. Retratada como "centralizadora e de temperamento forte" (edição no 2474), Dilma é acusada de ser arrogante, "mandona e irritadiçac" (edição no 2478). É o que se observa nos seguintes trechos: "Autocrítica nunca foi o forte da presidente, e isso certamente ajudou a fomentar a antipatia da população" (edição no 2474); "Dilma, cuja dificuldade para reconhecer os próprios erros tem contornos patológicos" (edição no 2478); "Mais uma vez, não teve a humildade de fazer mea-culpa" (edição $\mathrm{n}^{\circ}$ 2478). Esse tratamento relaciona-se com o fenômeno do double-bind. Ao mesmo passo em que características de Dilma - como seu "temperamento forte", a postura centralizadora e o fato de ser "mandona" - são criticadas, o oposto acontece com Temer. Em diversas ocorrências, como na matéria "A hora e a vez do vice”, pertencente à edição n 2474 de Veja, é exigido de Temer, conhecido por sua postura "afável e conciliadora", que seja mais arrojado e tome as rédeas do país. $\mathrm{O}$ mesmo discurso aparece na matéria "As missões de Temer", pertencente à edição n 2439 de IstoÉ. Retratado como "hábil negociador", de "natureza equilibrista", a publicação diz que Temer "terá, no entanto, de aprender a dizer não", pois "muitos o criticam por ceder demasiadamente".

Outros momentos em que os estereótipos de gênero são reforçados relacionam-se com os mecanismos implícitos e explícitos atrelados à exclusão das mulheres do campo político (MATOS, 2015; MIGUEL; BIROLI, 2009; SARMENTO, 2013). Na edição n 2478, na matéria "A Despedida", Veja afirma: "Dilma nunca teve pretensões eleitorais. Se for cassada, voltará a morar em Porto Alegre, dedicando-se à filha e aos dois netos, à leitura e, eventualmente, assistir a peças de teatro". Neste trecho, destaca-se uma suposta inaptidão de Dilma para 
a política e são reforçados comportamentos historicamente atribuídos às mulheres: manter-se aos limites do doméstico, devotadas aos cuidados dos filhos e netos, dedicando-se à leitura e a peças de teatro, bem como - e sobretudo - longe do debate público.

Nesse sentido, também se enquadram as matérias que tratam da ex-primeira-dama Marcela Temer - considerada "bela, recatada e 'do lar"” (Veja, edição no 2474), apresentada como uma espécie de contraponto a tudo o que é criticado em Dilma. A matéria destaca suas qualidades estritamente "femininas": mesmo formada não exerce a profissão, é uma "vice-primeira-dama do lar", que se dedica a cuidar da casa e do filho do casal enquanto o marido trabalha, "e um pouco dela mesma também", frequentando salões de beleza e consultórios dermatológicos rotineiramente. Definida como recatada, com gosto por vestidos até os joelhos e cores claras, destaca-se que "em todos esses anos de atuação política do marido, ela apareceu em público pouquíssimas vezes". O mesmo ocorre na matéria "Marcela Temer entra em cena", da edição no 2439 de IstoÉ, que sublinha que durante os anos em que Michel Temer foi vice-presidente, "ela fez o maior esforço para se manter incógnita, por mais tumulto que suas raras aparições públicas e poucas palavras causassem". Em outro trecho, a responsabilidade por essa postura "discreta" é atribuída ao marido: "Até hoje, Temer procurou restringir as aparições da mulher a ocasiões consideradas fundamentais, como, por exemplo, às cerimônias da posse presidencial de 2011 e de 2015, quando ela se tornou um dos assuntos mais comentados no Twitter mundial". A publicação também comenta que, mesmo advogada por formação, Marcela não chegou a exercer a profissão e durante todo o tempo de vice-presidência de Temer optou por morar em São Paulo com filho, onde "permanecia longe da política, dos holofotes", "cuidava do filho, da casa e ia à academia" (IstoÉ, edição n 2439).

\section{Análise das estratégias retóricas}

Embora os recursos retóricos no jornalismo sejam frequentemente associados aos estudos de valores noticiosos - os chamados "valores-notícia de construção" (TRAQUINA, 2008), por exemplo - vale-se aqui da opção metodológica de Jim Kuypers (2009), que vincula o escopo da análise retórica ao contexto da framing analysis. Para o autor, a ação de proporcionar enquadramentos da realidade a partir da prática jornalística não se institui dissociada do estabelecimento de estratégias retóricas. Nesse sentido, a partir de uma leitura crítica ao conceito de "valores-notícia de construção", compreende-se neste estudo que categorias como a "simplificação", a "amplificação", a "relevância" e a "personalização", podem ser interpretadas mais pertinentemente como estratégias argumentativas típicas da retórica - tal como o emprego de figuras de linguagem e de técnicas de argumentação, que "cumprem a função de redefinir um determinado campo de informação, criando efeitos novos e que sejam capazes de atrair a atenção do receptor" (CITELLI, 2003, p.19-20) - o que revela-se especialmente no âmbito das revistas estudadas, explicitando novamente estereótipos de gênero.

A "simplificação" ou o fato de o acontecimento ser desprovido de ambiguidade e complexidade, é exemplificada por Traquina (2008, p.91) como o "uso de clichês, estereótipos e ideias feitas", que servem para "tornar a notícia menos ambígua" e "reduzir a natureza polissêmica do acontecimento". Se para o autor português este constitui um recurso necessário para os jornalistas na produção de notícias de fácil compreensão, identifica-se no contexto do presente estudo, sob o vértice da produção de sentidos, que a utilização dessa estratégia por Veja e IstoÉ no processo de impeachment de Dilma Rousseff remete à abreviação da complexidade da temática. Isso se manifesta na maneira como os problemas enfrentados pelo país no período que antecede a deposição da ex-presidenta são diretamente 
relacionados a ela (sublinhando, uma vez mais, o fenômeno do double-bind), desconsiderando o cenário complexo e marcado por tensionamentos com os demais poderes (legislativo e judiciário) e por fatores externos, como o contexto econômico internacional. Da mesma forma, tal recurso manifesta-se na maneira como o impeachment é apresentado de maneira direta como a única alternativa para mudar os rumos do país.

Na capa da edição no 2401 de IstoÉ, a manchete "O que falta para ela sair?" e a afirmação em destaque de que a "abertura do processo de afastamento da presidente deve tirar o Brasil da paralisia" exemplificam a utilização da simplificação e um esvaziamento da complexidade no tratamento do tema.

Figura 3 - Capa da edição no $2401,09 / 12 / 2015$, IstoÉ

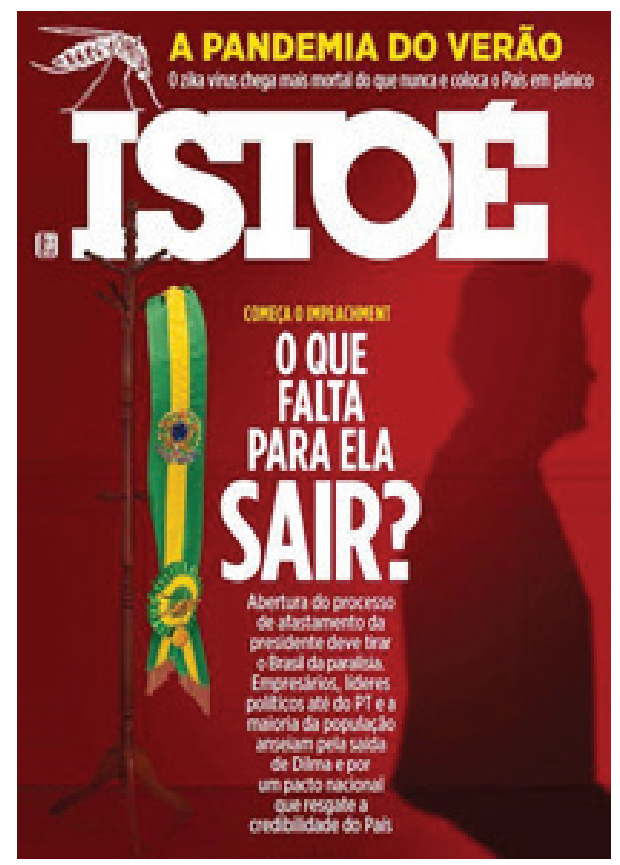

A simplificação pode ser relacionada também ao estudo das fontes. Nota-se, como demonstrado anteriormente, que ambas as revistas não lançam mão da prática de apontar o contraditório, o que resulta invariavelmente na simplificação - ou no esvaziamento da complexidade - das perspectivas apresentadas. Tal estratégia vincula-se ainda a outra figura retórica, a "personalização", ou a supervalorização das personas envolvidas no acontecimento em detrimento das problemáticas.

A estratégia da personalização se manifesta principalmente na relação que Veja e IstoÉ fazem dos entraves políticos e econômicos do país com a figura de Dilma Rousseff. A ex-presidenta aparece representada visualmente ou mencionada diretamente em um terço de todas as capas de dezembro de 2015 a setembro de 2016 (período de tramitação do processo de impeachment) da revista Veja e em praticamente metade de IstoÉ. Infere-se, desse modo, que a personalização se manifesta em diversas ocasiões dentro do corpus que compõe a análise, a exemplo da matéria "Dilma cai no limbo" (Veja, edição no 2474 ), na qual a estratégia retórica é explicitada logo na escolha do título. No decorrer do texto, a ex-presidenta é também responsabilizada diretamente pelos problemas verificados durante o governo. A revista chega a afirmar que "sua queda é uma obra pela qual ninguém mais do que ela pode responder". Na edição no 2419 de IstoÉ, apresentada como "Edição Especial Impeachment", o recurso também aparece de antemão na capa, com uma silhueta do rosto de Dilma preenchida com diversas acusações referentes a seu governo: 
Figura 4 - Capa da edição no 2419, 20/04/2016, IstoÉ

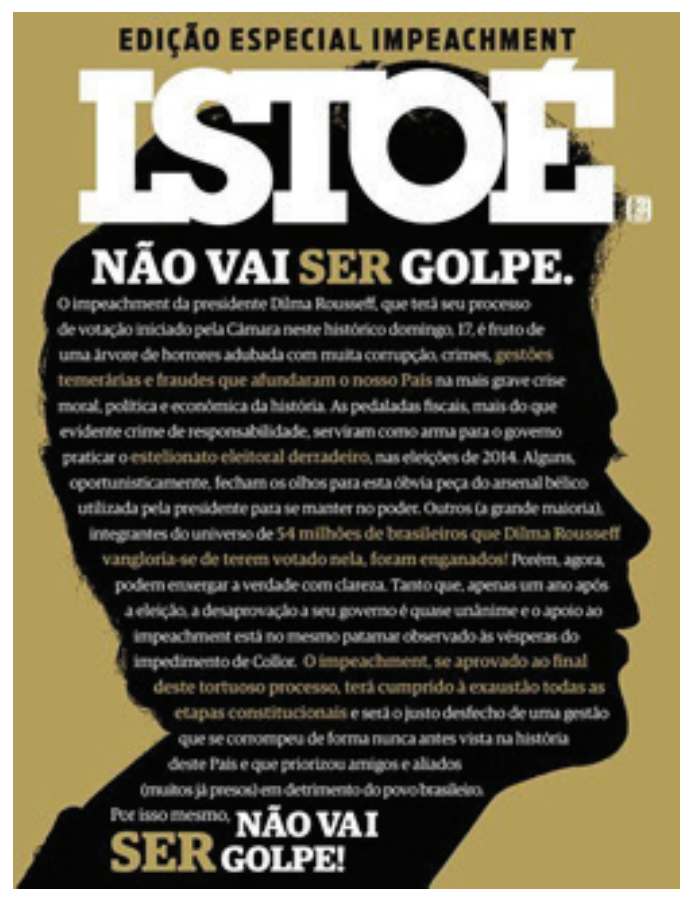

Outras estratégias retóricas verificadas nas dinâmicas de enquadramento de Veja e IstoÉ são a "amplificação" (ou seja, quanto mais amplificado é o acontecimento, mais possibilidades tem a notícia de ser notada, quer seja pela amplitude do ato ou por suas consequências) e a "relevância" (que se refere à habilidade do jornalista de construir a narrativa de modo a conceder um valor simbólico ao acontecimento como se este apresentasse uma relevância única para todas as pessoas). Tais estratégias estabelecem-se como recursos retóricos identificados em matérias como "Impeachment não é guerra" (Veja, edição no 2455), "A era Dilma se aproxima do fim" (IstoÉ, edição $\mathrm{n}^{\circ}$ 2436), entre outros exemplos. O uso de generalizações, nas quais "o Brasil” ou "os brasileiros" aparecem representados como um todo único, deslocados de suas particularidades e complexidades, caracteriza ambas as categorias e apresenta-se como uma estratégia tanto para amplificar a cobertura do processo de impeachment quanto para gerar identificação com o público atingido pelas publicações.

De modo geral, verifica-se que estratégias retóricas como a simplificação, a amplificação, a relevância e a personalização constituem-se recursos argumentativos implicados no enquadramento, sendo utilizados por Veja e IstoÉ para apresentar as notícias relacionadas ao processo de impeachment de Dilma de maneira enviesada, reforçando mais uma vez desequilíbrios no tratamento das questões de gênero. Entende-se particularmente que a "simplificação" e a "personificação" são identificadas principalmente na maneira como todos os problemas enfrentados pelo país no período que antecede a deposição da ex-presidenta são diretamente relacionados à sua persona, num processo que remete ao fenômeno do double-bind. Por fim, a "simplificação" manifesta-se também na maneira como o impeachment da primeira presidenta brasileira eleita na história é apresentado de maneira direta como a inequívoca alternativa para alterar os destinos do país - o que, em última instância, ajuda a consolidar o que Miguel e Biroli (2008, p.25) denunciam como visão de realidade social que tende "a confirmar e naturalizar as visões já incorporadas pelos agentes (homens e mulheres) com relação às hierarquias de gênero”.

\section{Considerações finais}

Ainda que as mulheres tenham conquistado nas últimas décadas direitos importantes na luta pela igualdade de gênero, o cenário contemporâneo mostra- 
-se o de uma sociedade estruturalmente sexista. Nesse contexto, a opção metodológica de se estudar o impeachment de Dilma Rousseff sob a ótica dos estudos de gênero se justifica a partir do pressuposto de pesquisa trabalhado na abertura do artigo de que homens e mulheres não podem ser analisados em posição de igualdade (BEAUVOIR, 1970; VIEZZER, 1989), seja na sociedade em geral ou nas especificidades do cenário político e midiático (MATOS, 2015; MIGUEL; BIROLI, 2009; SARMENTO, 2013).

Ao chegar ao mais alto cargo da política brasileira, Dilma teve de enfrentar durante seus anos de mandato desafios diferentes dos já conhecidos pelos políticos homens. No decorrer da análise, em cada elemento considerado no interior do modelo de enquadramento multimodal, foram identificadas questões diretas e indiretas relacionadas à disparidade de gênero. Com relação às funções clássicas do enquadramento noticioso (ENTMAN, 1993), Veja e IstoÉ apresentam resultados semelhantes. No que tange à "definição de problemas", em diversos momentos a ex-presidenta é responsabilizada diretamente pelo conjunto dos problemas do país. Enquanto IstoÉ se isenta de fazer um "diagnóstico de causas" para tentar identificar as forças que criam os problemas, Veja o faz de forma não aprofundada. Quanto às "soluções sugeridas", o impeachment é apresentado de maneira direta como alternativa inescapável. Os “julgamentos morais", presentes em todas as matérias das revistas, reforçam a tese. Do fato de o próprio Michel Temer não ter sido acusado pelas publicações de ter cometido atos criminosos, ainda que o processo eleitoral dissesse respeito à chapa de ambos, infere-se uma relação direta com às questões de gênero (MIGUEL, BIROLI, 2009; SARMENTO, 2013). Os demais julgamentos morais, que se associam à temática de gênero, são referentes a características de Dilma, retratada como "centralizadora e de temperamento forte" (Veja, edição no 2474,), e acusada de ser arrogante, "mandona e irritadiça" (Veja, edição no 2478). Isso ajuda a explicar por que Dilma é constantemente criticada por características que são não apenas valorizadas nos homens, mas também exigidas. Enquanto supostas características de Dilma - como seu "temperamento forte", sua postura centralizadora e o fato de ser "mandona" - são criticadas, o oposto acontece com Temer, vice-presidente que chegou ao poder com a deposição da ex-presidenta.

Dinâmicas semelhantes são identificadas na análise das fontes jornalísticas, dos canais de informação e das estratégias retóricas. Em relação às fontes e canais, infere-se que, embora no centro do processo, Dilma Rousseff não é mobilizada em momento algum por meio do canal corporativo, sendo jornalisticamente mencionada de forma oficialesca pelo recurso de notas e de pronunciamentos genéricos, o que não ocorre com seus pares e adversários políticos. Os homens, aliás, constituem um volume bastante desproporcional entre as fontes primárias e secundárias legitimadas como vozes autorizadas pelas revistas. No âmbito das estratégias retóricas, em especial no terreno da "simplificação" e da "personalização", infere-se a recorrência de construções discursivas que acabam por reforçar o fenômeno histórico do double-bind (JAMIESON, 1995; CATALYST, 2007).

Todas essas problemáticas devem ser inseridas em uma visão do enquadramento jornalístico do impeachment de Dilma Rousseff a partir de uma perspectiva mais ampla e multifacetada, uma vez que o universo midiático possui tensionamentos intrínsecos e extrínsecos com a sociedade por meio de "quadros primários de referência”, tal como proposto por Erving Goffman (2012); isto é, de esquemas fundamentais de compreensão e de interpretação que auxiliam os indivíduos no entendimento dos acontecimentos. $\mathrm{O}$ acesso à cobertura midiática detém grande relevância na medida em que - de acordo com Miguel e Biroli $(2009$, p.25) - "as diferenças de gênero, tomadas como diferenças estruturais, têm a mídia como parte de procedimentos que reforçam a estrutura de relações e interações constituídas". Esse acesso "é condicionado pelas percepções dos agentes do campo jornalístico 
sobre o que é notícia e quem está dotado de autoridade para falar sobre determinadas questões" (MIGUEL; BIROLI, 2009, p.25).

Nesse sentido, na medida em que a mídia reivindica para si o caráter de isenção, os pontos de vista daqueles que controlam as empresas e têm posições de poder na produção jornalística se impõem como visões objetivas da realidade social através das rotinas produtivas da construção midiática. Uma vez mais, portanto, a produção de bens simbólicos pelas instâncias midiáticas encontra sintonia com o cenário histórico - traduzido em quadros primários de referência (GOFFMAN, 2012) - que contribui e ratifica o afastamento e a discriminação das mulheres dos espaços coletivos de deliberação (MATOS, 2015). As variáveis multimodais identificadas no enquadramento jornalístico do impedimento de Dilma Rousseff ratificam o fenômeno, apresentando elementos que podem subsidiar políticas para a superação do quadro de desigualdade de gênero.

\section{Referências}

ASSOCIAÇÃO NACIONAL DE EDITORES DE REVISTA (ANER). Disponível em: <http://aner.org.br/>. Acesso em: 10 abr. 2021.

BEAUVOIR, S. O segundo sexo: Fatos e Mitos. 4. ed. São Paulo: Difusão Européia do Livro, 1970. 309 p.

CATALYST. The Double-Bind Dilemma for Women in Leadership. 2007. Disponível em: <https://www.catalyst.org/knowledge/double-bind >. Acesso em: 10 dez. 2018.

CITELLI, A. Linguagem e persuasão. 15. ed. São Paulo: Ática, 2003.

D’ANGELO, P. News Framing as a Multiparadigmatic Research Program: A Response to Entman. Journal of Communication, Research Library Core, v. 52, ed. 4, p. 870-888, dez. 2002.

ENTMAN, R. M. Framing: Toward Clarification of A Fractured Paradigm. Journal of Communication, Research Library Core, v. 43, ed. 4, p. 51-58, dez. 1993.

GOFFMAN, E. Os quadros da experiência social: Uma perspectiva de análise. Petrópolis: Editora Vozes, 2012.

JAMIESON, K. H. Beyond the double bind: Women and leadership. New York: Oxford University Press, 1995.

KUYPERS, J. A. (Org.). Rhetorical Criticism: perspectives in action. New York: Lexington Books, 2009.

MATOS, M. Democracia, sistema político brasileiro e a exclusão das mulheres: a urgência em aprofundar estratégias de descolonização e despatriarcalização do Estado. Revista Observatório Brasil da Igualdade de Gênero. Brasília: Secretaria de Políticas para as Mulheres, p. 24-37, 2015.

MIGUEL, L. F.; BIROLI, F. Gênero e política no jornalismo brasileiro. FAMECOS, Porto Alegre, n. 36, p. 24-39, ago. 2008.

MIGUEL, L. F.; BIROLI, F. Mídia e representação política feminina: Hipóteses de pesquisa. Opinião Pública, Campinas, v. 15, n. 1, p. 55-81, jun. 2009. 
RIZZOTTO, C.; PRUDENCIO, K.; SAMPAIO, R. A despolitização no enquadramento multimodal da cobertura do impeachment de Dilma Rousseff. Comunicação \& Sociedade, São Bernardo do Campo, v. 39, n. 3, p. 111-130, set./ dez. 2017.

SARMENTO, R. Estereótipos de mulheres políticas na mídia: quadros de análise com base em entrevista de Dilma Rousseff a Patrícia Poeta. Cadernos da Escola do Legislativo, Belo Horizonte, v. 15, n. 23, p. 3-21, jan./jun. 2013.

SIGAL, L. V. Reporters and Officials: The Organization and Politics of Newsmaking. 2 ed. Estados Unidos: D.C. Heath and Company, 1974.

SOLEY, L. C. The News Shapers: The Sources Who Explain the News. New York, Westport, London: Praeger Publishers, 1992.

TRAQUINA, N. Teorias do Jornalismo: A tribo jornalística - uma comunidade interpretativa transnacional, 2. ed. Florianópolis: Insular, 2008.

VIEZZER, M. O problema não está na mulher. São Paulo: Cortez, 1989. 173 p.

WOSNIAK, A.; LÜCK, J.; WESSLER, H. Frames, Stories, and Images. Environmental Communication, v. 9, ed. 4, p. 469-490, dez. 2014.

ZAMIN, Â. Jornalismo de referência: o conceito por trás da expressão. Revista Famecos, Porto Alegre, v. 21, n. 3, p. 918-942, set-dez 2014. 